\title{
Analisis Tingkat Literasi Nasabah Bank Syariah pada Kontrak Murabahah
}

\author{
Asmaul Husna ${ }^{1}$, Marliyah ${ }^{2 *}$, Haris Al Amin ${ }^{3}$, Julfan Saputra ${ }^{4}$, Wahyu Syarvina ${ }^{5}$ \\ 1,2,4,5 Universitas Islam Negeri Sumatera Utara, Medan, Provinsi Sumatera Utara, \\ Indonesia. \\ ${ }^{3}$ Politeknik Negeri Lhokseumawe, Kota Lhokseumawe Provinsi Aceh, Indonesia.
}

\begin{abstract}
Abstrak. Tujuan penelitian ini adalab untuk mengkaji tingkat pemahaman nasabab bank syariah yang telah melakukan akad murabahah, serta faktor-faktor yang mempengarubi keputusan nasabah menggunakan bank syariah untuke pembiayaan murabahah. 45 nasabab bank syariah yang telah mengambil pembiayaan murabahah dipilih sebagai sampel. Data yang digunakan adalah data primer yang dikumpulkan dari nasabah yang telah mengambil pinjaman murabahah melalui survei dan wawancara langsung. Pendekatan analitik kualitatif digunakan dalam analisis data. Temuan menunjukkan bahwa mayoritas nasabah tidak mengetahui pengaturan pembiayaan murababah.
\end{abstract}

Kata kunci: Akad Murababab; Pembiayaan Murabahab; Tingkat Pemahaman Nasabah.

\begin{abstract}
The purpose of this research is to examine the level of understanding of Islamic bank customers who have entered into murabahah contracts, as well as the factors that influence customer decisions to use Islamic banks for murabahah financing. 45 Islamic bank customers who bave taken murababa financing were selected as samples. The data used is primary data collected from customers who have taken murabaha credit through surveys and direct interviews. Qualitative analytical approach was used in data analysis. The findings show that customers are not aware of the murabahah financing arrangements.
\end{abstract}

Keywords: Murababah Contract; Murabahah Financing; Customer Understanding Level.

*Author. Email: asmaul25husna@gmail.com ${ }^{1}$.marliyah@uinsu.ac.id 2*, haris@pnl.ac.id ${ }^{3}$, julfansaputra91@gmail.com ${ }^{4}$,wahyusyarvina@uinsu.ac.id 5. 


\section{Pendahuluan}

Pada saat ini, kehidupan ekonomi internasional tidak dapat dipisahkan dari dunia perbankan. Hampir semua kegiatan perusahaan mengandalkan jasa bank sebagai lembaga keuangan untuk menjamin kelancaran operasionalnya. Selanjutnya, bank adalah lembaga keuangan yang menyediakan dana atau modal dalam bentuk pinjaman kepada pelaku usaha. Selanjutnya, bank adalah lembaga keuangan yang menyediakan dana atau modal dalam bentuk pinjaman kepada pelaku usaha. Lembaga keuangan bank (bank) di Indonesia dapat dibedakan menjadi dua jenis: lembaga keuangan tradisional dan lembaga keuangan syariah.

Meski kesadaran masyarakat dan sosialisasi produk perbankan masih terbatas, peran perbankan dalam mendorong pertumbuhan ekonomi merupakan strategi pertumbuhan. Perilaku nasabah terhadap produk keuangan perbankan dapat dipengaruhi oleh sikap dan persepsi masyarakat terhadap karakteristik perbankan itu sendiri. Dengan memahami level pemahaman atau preferensi masyarakat terhadap produk keuangan perbankan, maka bank memiliki peluang yang kuat untuk mendesain produk yang ditawarkan menjadi lebih digerakkan oleh pasar. Struktur pengetahuan dan pemahaman masyarakat yang ada sudah sangat lama dibangun, tentunya tidak mudah untuk diarahkan pada sistem perbankan yang tumbuh seiring dengan perkembangan dan pembangunan ekonomi kebutuhan lalu lintas keuangan.

Sebagaimana tercantum dalam Pasal 13 Undang-Undang Nomor 10 Tahun 1998 yang merevisi Undang-Undang Nomor 7 Tahun 1992 tentang Perbankan, kedudukan perbankan syariah tampak lebih jelas dan tegas "Prinsip Syariah adalah aturan perjanjian berdasarkan hukum Islam antara bank dengan pihak lain untuk menyimpan dana dan atau pembiayaan kegiatan usaha, atau kegiatan lainnya yang dinyatakan sesuai dengan syariah, antara lain pembiayaan berdasarkan prinsip bagi hasil (mudharabab), pembiayaan berdasarkan prinsip penyertaan modal (musharakah), prinsip jual beli barang dengan memperoleh keuntungan (murabahah), atau pembiayaan barang modal berdasarkan prinsip sewa murni tanpa pilihan (jarah), atau dengan adanya pilihan pemindahan kepemilikan atas barang yang disewa dari pihak bank oleh pihak lain (ijarah wa iqtina). Pembiayaan syariah juga dibahas pada undang-undang ini, sebagaimana disebutkan dalam pasal 12 yang berbunyi "Pembiayaan berdasarkan Prinsip Syariah adalah penyediaan uang atau tagihan yang dipersamakan dengan itu berdasarkan persetujuan atau kesepakatan antara bank dengan pihak lain yang mewajibkan pihak yang dibiayai untuk mengembalikan uang atau tagihan tersebut setelah jangka waktu tertentu dengan imbalan atau bagi hasil”.

Meskipun persoalan perbankan dengan struktur bagi hasil hanya dibahas secara singkat, perjalanan bank syariah di Indonesia dimulai dengan berdirinya Bank Muamalat Indonesia (BMI) pada tahun 1991 berdasarkan UndangUndang Nomor 7 Tahun 1992. Sejak krisis ekonomi tahun 1998, sistem keuangan Islam baru-baru ini diteliti. Bank Indonesia saat itu melakukan due diligence terhadap semua bank nasional, dan BMI yang saat itu baru berdiri beberapa tahun dan merupakan satu-satunya bank yang beroperasi dengan prinsip syariah, menempati urutan ke-43 dari 208 bank yang ada. Sejak saat itu, beberapa bank konvensional mulai tertarik dengan bank syariah dan mulai menyediakan dan menyelenggarakan pelatihan perbankan syariah bagi karyawannya.

Peneliti sangat tertarik dengan topik ini karena ingin melihat sejauh mana pemahaman akad murababah ini. Tema ini dianggap perlu untuk dikaji dan sangat bermanfaat dari sisi nasabah maupun dari sisi bank-bank syariah. Selanjutnya penulis menekankan perlunya nasabah memahami akad yang mereka tandatangani, sehingga jika terjadi perselisihan antara nasabah dan bank, nasabah akan lebih mengetahui apakah peraturan yang berlaku sudah sesuai dengan kenyataan.

\section{Literature Review}

\section{Pengertian Murabahah}

Murababah berasal dari arti linguistik ataupun etimologis dari kata "ribb", yang berarti keuntungan ataupun perkembangan nilai modal. Murabahah merupakan wujud timbal balik yang 
menunjukkan "satu sama lain". Murabahah, setelah itu, mengacu pada suasana di mana kedua belah pihak menemukan untung. Murabahah dimaksud selaku menjual dengan modal asal serta keuntungan yang jelas dalam ilmu fiqih

Murabahah, menurut Widodo (2010) "hanyalah jual beli", ialah jual beli yang bisa dibayar tunai ataupun bagi konvensi antara kedua belah pihak. Murababah didefinisikan oleh Antonio (2001), Nurhayati \& Wasilah (2016), Ikatan Akuntansi Indonesia (IAI) (2009), Zaid \& Rehman, 2020), serta Rachmawati, Karim, \& Manan, (2019) selaku jual beli dengan harga beli yang sudah didetetapkan serta bonus keuntungan yang disepakati. Murabahah, di sisi lain, merupakan wujud jual beli daripada meminjam duit.

Murabahah dibagi menjadi dua jenis menurut Nurhayati dan Wasilah (2016): 1) Murabahab tanpa perintah dan 2) Murababab dengan perintah. Dengan adanya perintah murabahab kepada pembeli, Antonio (2001) menggunakan istilah murababah (murababah KPP). Ketika penjual membeli produk setelah menerima pesanan dari pembeli, ini dikenal sebagai murabahah dengan pesanan. Dengan suatu pesanan, Murabahah dapat mengikat atau melepaskan pembeli untuk membeli barang yang ditentukan.

Murabahab didefinisikan oleh Saeed (2004) sebagai suatu bentuk jual beli berbasis komisi dimana pembeli pada umumnya hanya dapat memperoleh objek yang diinginkannya melalui perantara, atau ketika pembeli tidak mau melalui kesulitan untuk mendapatkannya sendiri. Jadi dia mencari jasa perantara. Murabahah, menurut Antonio (2001), adalah "jual beli barang dengan harga asli ditambah bonus keuntungan yang disepakati." Penjual harus menyerahkan informasi tentang harga barang yang diperolehnya dan menaikkan tingkat tambahan dalam kontrak ini.

Murabahab didefinisikan oleh Sudarsono (2004) sebagai tindakan membeli dan menjual barang pada harga aslinya ditambah insentif keuntungan yang disepakati antara bank dan konsumen. Penjual memberi tahu pembeli tentang harga pembelian produk setelah ia mengajukan sejumlah keuntungan tertentu dalam murabahah.

Dari bermacam definisi tersebut bisa disimpulkan sebagian perihal pokok kalau akad murabahah ada:

1. Pembelian benda dengan pembayarannya bisa dicoba melalui tunai (naqdan) ataupun Tangguh (bi thaman ajil),

2. Benda yang dibeli memakai harga pokok,

3. Ada bonus keuntungan (komisi, mark up harga, laba) dari harga asal yang sudah disepakati,

4. Ada konvensi antara kedua belah pihak (pihak bank serta nasabah) ataupun dengan kata lain terdapatnya kerelaan di antara keduanya,

5. Penjual wajib mengatakan harga benda kepada pembeli (berikan ketahui harga produk).

\section{Landasan Syariah Akad Murabahah}

Dalam muamalah, para ulama fiqh telah membahas berbagai macam akad jual beli. Ada tiga macam akad jual beli yang perlu dilaksanakan dan dibuat pada masa Rasulullah Shallallahu 'alaihi wa sallam dan para sahabatnya sebagai penopang utama investasi dan pembayaran modal kerja, di antara berbagai jenis jual beli tersebut. kontrak. Ketiga akad tersebut, bai'as-salam, bai' al-istishna, dan bai' al-murabahah, saat ini sedang dikembangkan dalam aplikasi perbankan syariah saat ini.

Secara umum, para ekonom perbankan syariah mengatakan bahwa jual beli murabahab diperbolehkan sebagai transaksi pembiayaan perbankan. Mereka dibimbing oleh Al-Qur'an dan hadits dalam situasi ini. Menurut para akademisi, tidak ada ayat yang eksplisit dalam Al-Qur'an atau hadits yang merujuk pada murabahah. Ayat-ayat Al-Qur'an dan hadits tentang jual beli secara umum lebih umum, sebagaimana tercantum dalam Q.S. al-Baqarah ayat 275 tentang kebolehan jual beli.

Para ulama telah menetapkan murabahab menjadi halal, menurut Antonio (2001), karena ruang lingkup nalar yang menjelaskan kebolehan jual beli dalam skala besar. Kebulatan suara para ulama menjadi dasar kebolehan murabahab ini karena jual beli ini terjadi di semua 
tempat dan di setiap waktu. Orang yang tidak memiliki kemampuan membeli dan menjual mungkin mengandalkan orang lain sambil mempertahankan rasa ketenangan di hati mereka. Menurut perjanjian, dia dapat membeli produk dan menjualnya untuk mendapatkan keuntungan yang layak.

Landasan syariah berikutnya adalah dibolehkannya jual beli secara tidak tunai. Yaitu Q.S. al-Baqarah [2]: 282 yang berbunyi: "Hai orang-orang yang beriman, apabila kamu bermu'amalah [seperti berjualbeli, utang piutang, atau sewa menyewa dan sebagainya] tidak secara tunai untuk waktu yang ditentukan, bendaklab kamu menuliskannya"

Ayat ini ditunjukkan kepada orang-orang beriman, tetapi yang dimaksud adalah mereka yang melakukan transaksi utang piutang, bahkan yang lebih khusus adalah yang berutang. Ini agar yang memberi piutang merasa lebih tenang dengan penulisan itu, karena menulisnya adalah perintah atau tuntunan yang sangat dianjurkan, walau kreditor tidak memintanya.

\section{Rukun dan Syarat Murabahah}

1. Rukun Murabahab

Nurhayati \& Wasilah (2016) mengatakan bahwa murabahah mempunyai beberapa rukun yaitu,

a) Para pihak (al-'aqidan)

b) Pernyataan kehendak (sigat al-'aqd

c) Objek akad (mahall al-'aqd)

Di sisi Hanafi, rukun jual beli adalah penawaran (ijab) dan penerimaan (qabul), yang menunjukkan legalitas pertukaran barang. Dengan kata lain, dasar dari jual beli adalah pernyataan atau perilaku yang menunjukkan keinginan untuk memperdagangkan produk. Penjual, pembeli, frase, dan produk yang dikontrakkan masing-masing merupakan empat pilar akad jual beli (Zuhayli, 2004).

2. Syarat murabahah

Terdapat delapan syarat terbentuknya akad murabahah, yaitu:

a) Dapat membedakan yang baik dan buruk atau cakap dalam melakukan tindakan hukum (at-tamyiz), b) Berbilang pihak (ta'addud at-tarfain),

c) Pertemuan kehendak atau kesepakatan (tatabuq al-iradatain),

d) Kesatuan majlis (ittihad at-tarfain),

e) Objek ada pada waktu akad [dapat diserahkan],

f) Objek dapat ditransaksikan (salabiyah almal li at-ta'amuli),

g) Objek tertentu atau dapat ditentukan (at-ta'yin an qabiliyyah al- mabal li atta'amuli),

h) Tidak bertentangan dengan ketentuan syariah ('adamu mukhalafah asy-syar'i).

Karakteristik utama dari akad murabahah yang sedang diselidiki, seperti yang disarankan oleh Saeed (2004), termasuk dalam klausul murabahah yang tercantum di atas. Unsur-unsur penting dari kontrak murabahah adalah bahwa; 1) pembeli harus menyadari biaya terkait dan harga asli barang; 2) mark-up harus dinyatakan sebagai persentase dari seluruh harga dan biaya; 3) Barang yang diperjualbelikan harus ada dan dimiliki oleh penjual, serta kemampuan penjual untuk menyerahkan produknya kepada pembeli; 4) pembayaran ditangguhkan. Murabahah adalah jenis pembiayaan yang digunakan ketika ada sesuatu yang nyata untuk dijual.

\section{Fatwa Dewan Syariah Nasional Tentang Murabahah}

1. Fatwa Dewan Syariah Nasional Nomor 23/ DSN-MUI/III/2002 tanggal 28 Maret 2002, dipaparkan tentang potongan pelunasan dalam murabahah. Nasabah yang tidak/belum mampu membayar disebabkan force majeur tidak boleh dikenakan sanksi. Namun untuk nasabah mampu yang menunda-nunda pembayaran dan/atau tidak mempunyai kemauan dan itikad baik untuk membayar hutangnya boleh dikenakan sanksi. Sanksi tersebut diakui bank sebagai dana sosial.

2. Fatwa Dewan Syariah Nasional Nomor 17/ DSN-MUI/IX/2000 tanggal 16 September 2000, dipaparkan tentang sanksi atas nasabah mampu yang menunda-nunda pembayaran. Jika nasabah dalam transaksi murabahah melakukan pelunasan pembayaran tepat waktu atau lebih cepat dari waktu yang 
telah disepakati, bank boleh memberikan potongan dari kewajiban pembayaran tersebut, dengan syarat tidak diperjanjikan dalam akad.

3. Fatwa Dewan Syariah Nasional Nomor 16/ DSN-MUI/IX/2000 tanggal 16 September 2000, dipaparkan tentang diskon dalam murabahah. Harga dalam jual beli murabahah adalah harga beli dan biaya yang diperlukan ditambah keuntungan sesuai kesepakatan. Jika dalam jual beli murabahab bank mendapat diskon dari supplier, harga sebenarnya adalah harga setelah diskon, karena itu, diskon adalah hak nasabah.

4. Fatwa Dewan Syariah Nasional Nomor 13/ DSN-MUI/IX/2000 tanggal 16 September 2000, dipaparkan tentang uang muka dalam murabahah. Dalam akad pembiayaan murabahah, bank dibolehkan untuk meminta uang muka apabila kedua belah pihak sepakat dan besarnya uang muka ditentukan berdasarkan kesepakatan. Jika nasabah membatalkan akad murabahah, nasabah harus memberikan ganti rugi kepada bank dari uang muka tersebut.

Fatwa Dewan Syariah Nasional Nomor 04/ DSN-MUI/IV/2000 tanggal 1 April 2000, dipaparkan tentang ketentuan umum murabahah. Dalam murabahah dijelaskan bahwa harus terdapat akad antara bank dan nasabah yang bebas dari riba, lalu dijelaskan juga bahwa komoditas yang diperjualbelikan bukan barang haram, dan yang poin terakhir adalah bank membeli barang untuk nasabah atas nama bank sendiri, kemudian menjual kembali kepada nasabah sesuai harga beli ditambah margin.

\section{Metodologi Penelitian}

Penelitian ini menggunakan metode nonprobability sampling, dimana setiap elemen atau anggota populasi diberikan kesempatan atau kesempatan yang tidak sama untuk dipilih sebagai sampel. Karena peneliti tidak mengetahui jumlah sebenarnya dari populasi penelitian, maka digunakan juga nonprobability sampling. Sementara itu, peneliti akan mengadopsi teknik pengambilan sampel yang nyaman, di mana ia akan mengambil sampel dari lapangan. Di kota Medan, penulis mengambil sampel secara acak dari nasabah yang menggunakan bank syariah untuk pembiayaan. Untuk mendapatkan data yang akurat, penulis melakukan wawancara langsung (direct interview) dengan responden. Tujuannya adalah untuk menggeneralisasi tentang bagaimana nasabah di bank syariah memahami kontrak murabahah. Strategi ini juga digunakan mengingat terbatasnya sumber daya dan waktu penelitian yang tersedia.

Bagian pertama dari penelitian ini adalah menentukan topik penelitian, yaitu untuk menguji tingkat pemahaman konsumen terhadap akad murabahah pada bank syariah yang telah melakukan akad. Tahap kedua memerlukan menemukan landasan teoretis untuk membangun fondasi dalam pertanyaan kuesioner untuk menentukan tingkat pemahaman. Pembuatan kuesioner tentang pemahaman nasabah terhadap akad murababah merupakan tahap ketiga. Tahap keempat adalah menyebarkan sampel tes angket untuk menilai validitas dan reliabilitas pertanyaan.

Tahap kelima adalah dengan mengirimkan kuesioner kepada responden yang dalam hal ini adalah nasabah kredit angsuran bank syariah. Penulis mengolah data dan menguji statistik data setelah menerimanya dari hasil kuesioner (tahap keenam). Tahap terakhir melibatkan analisis temuan uji statistik yang akan digunakan untuk menarik kesimpulan dari penelitian ini.

Teknik analisis kualitatif digunakan untuk mengolah data. Metode ini menyalin data mentah yang dikumpulkan dari temuan wawancara terstruktur. Mengurutkan data (mengolah informasi yang diterima sehingga sistematis berdasarkan faktor-faktor yang diteliti) dan mengklasifikasikan data yang digunakan untuk mencapai hasil penelitian (mengklasifikasikan informasi yang telah disusun sebelumnya sehingga dapat dibandingkan oleh responden). Sedangkan analisis isi digunakan untuk menganalisis data (teknik yang digunakan untuk menarik kesimpulan melalui upaya menemukan ciri-ciri pesan yang dilakukan secara objektif dan sistematis). Jika responden dapat menjelaskan secara rinci pertanyaan peneliti, maka peneliti mengklasifikasikan responden sebagai sangat 
mengerti, cukup mengerti, tidak mengerti, dan tidak mengerti. Responden dicirikan sebagai cukup memahami jika mereka hanya dapat menjawab pertanyaan dari peneliti secara umum. Dan jika responden menjawab pertanyaan peneliti dengan cara yang mirip tetapi tidak identik dengan peraturan yang berlaku, maka jawaban tersebut masuk dalam kategori kurang pengetahuan. Namun, jika responden tidak dapat menanggapi peneliti dengan cara apa pun, masukkan mereka ke dalam kategori.

\section{Hasil dan Pembahasan}

Kuesioner ini penulis bagikan kepada 45 responden yang telah menandatangani akad pembiayaan murababah dan berdomisili di Medan. Responden rata-rata bekerja sebagai pekerja swasta, pegawai negeri, dan wiraswasta. Kuesioner terdiri dari 20 pertanyaan tentang peraturan kontrak murabahah saat ini. Penulis memisahkan 20 pertanyaan kuesioner menjadi tujuh segmen untuk menganalisisnya. Bagian pertama membahas akad murabahah, bagian kedua membahas manfaat perbankan syariah, dan bagian ketiga membahas biaya rumah, Bagian keempat membahas diskon bank syariah, bagian kelima membahas jaminan bank syariah, bagian keenam membahas denda bank syariah, dan bagian terakhir membahas pembayaran kembali bank syariah.

\section{Pemahaman Akad Murabahah}

Penulis ingin mengetahui seberapa besar tingkat pemahaman nasabah terhadap akad murabahah yang termasuk pemahaman akad murabahah dalam analisis pemahaman akad murabahah, perbedaan antara akad pembiayaan murababah dan kredit bank biasa, serta menentukan apakah nasabah mengetahui persyaratan yang mengharuskan bank untuk memiliki rumah secara langsung sebelum menjualnya kembali kepada nasabah.

Grafik 1 menunjukkan bahwa Mayoritas dari mereka yang disurvei tidak tahu apa itu akad murababah. Banyak dari mereka memiliki konsep yang salah tentang kontrak murabahab; mereka percaya itu adalah perjanjian bagi hasil (mudharabah). Ada klien yang paham karena bekerja di bidang keuangan, dan ada pula yang paham karena memiliki tingkat minat yang tinggi. Untuk pertanyaan tentang perbedaan akad murabahah dengan kredit kredit pada bank konvensional, rata-rata dari responden cukup paham dengan perbedaan ini. Hal ini dikarenakan mereka terlebih dahulu membandingkan akad murabahah pada bank syariah dengan pembiayaan pada bank konvensional sebelum mereka memutuskan untuk memilih akad murababah pada bank syariah. Beberapa hal yang mereka paham terhadap perbedaan ini adalah tentang cicilan yang flat sampai dengan akhir masa angsuran yang bila dibandingkan dengan bank

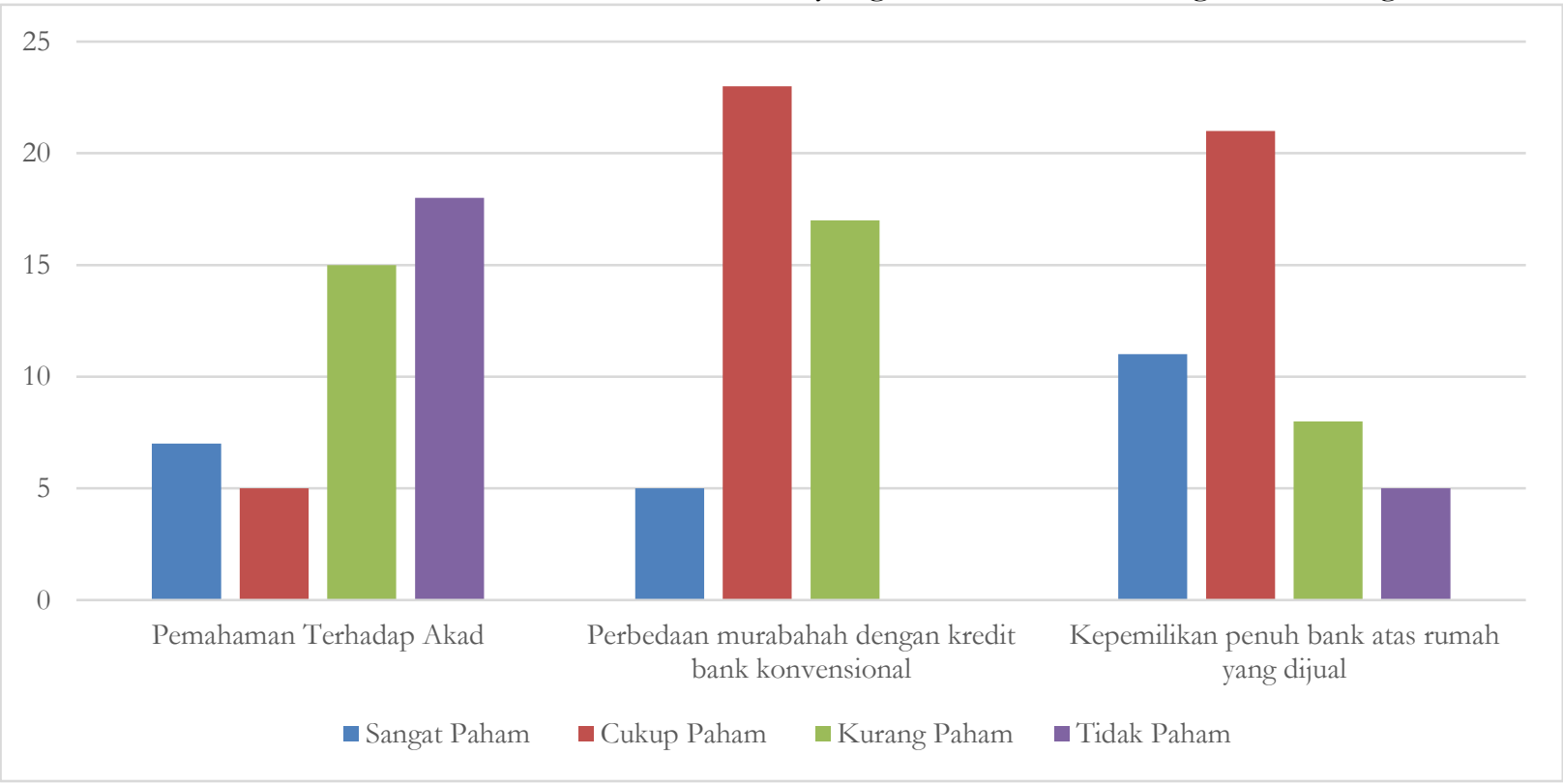

Grafik 1. Pemahaman Akad Murabahah 
konvensional yang cicilannya berubah-ubah mengikuti fluktuasi dari suku bunga. Ada juga beberapa responden yang melihat perbedaannya dari sisi Islami, yaitu ini hidup dengan rasa tenteram dan tenang karena dengan pembiayaan murababab mereka terhindar dari transaksi yang ribawi.

Mengenai ketentuan yang mengatur kepemilikan penuh bank terhadap rumah yang akan dijual kepada nasabah, sebagian besar nasabah paham akan peraturan ini. Dikarenakan kepemilikan rumah yang mereka beli dari pengembang maupun dari penjual perorangan sudah diatasnamakan bank terlebih dahulu baru setelah itu bank menjualnya lagi kepada nasabah, ada beberapa bank syariah yang baru akan mengubah kepemilikan rumah menjadi milik nasabah setelah nasabah melunasi angsurannya.

Persepsi nasabah yang terbiasa dengan kredit konvensional sehingga beranggapan tidak ada perbedaan antara pembiayaan dari bank syariah dengan kredit konvensional. Nasabah terpaku pada kredit konvensional karena faktor terbiasa oleh sistem kredit konvensional yang pada akhirnya membuat persepsi nasabah yang belum paham perbedaan produk pembiayaan bank syariah dengan kredit konvensional.

\section{Keuntungan Bank Syariah}

Studi penulis tentang tunjangan bank syariah ini berusaha untuk menentukan seberapa besar pemahaman klien tentang manfaat yang diterima bank syariah ketika mereka mengambil kontrak pembiayaan murabahah dan juga penulis ingin mengetahui apakah konsumen mengetahui undang-undang yang menyatakan bahwa keuntungan bank syariah dari flipping house dapat dinegosiasikan.

Ketika penulis melakukan wawancara dengan pelanggan, ia melihat bahwa setiap responden memiliki respon yang berbeda. Grafik 2 . mengungkapkan bahwa persepsi konsumen tentang ukuran pendapatan bank syariah sangat bervariasi, dan ini mungkin dikaitkan dengan tingkat keingintahuan responden sendiri. Ini karena jumlah keuntungan yang diperoleh bank syariah dapat dilihat dalam kontrak yang ditandatangani konsumen. Sementara itu, penulis menemukan kriteria yang berbeda dari bank syariah. Sementara itu, penulis menemukan kriteria yang berbeda pada bank syariah. Ada bank syariah yang secara lisan mencantumkan akad dalam murabahabnya, tetapi ada juga bank syariah yang tidak.

Sebagian besar responden, di sisi lain, tidak menyadari bahwa jumlah keuntungan yang
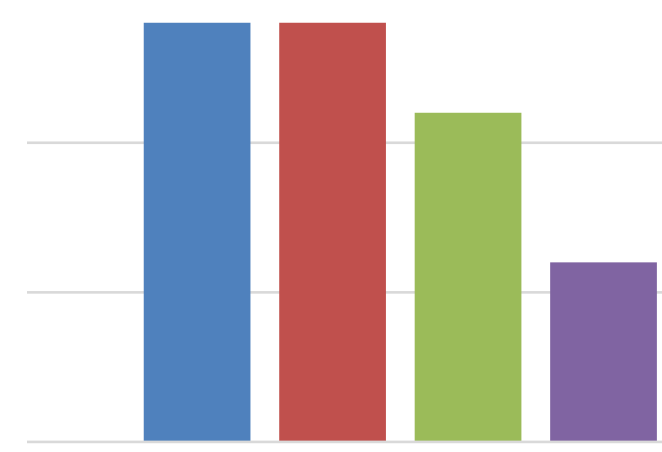

Besarnya Keuntungan Bank Syariah
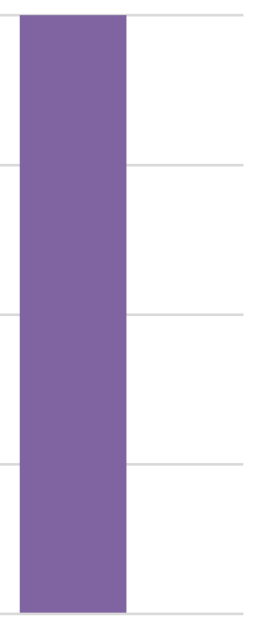

Margin Keuntungan Dapat Dinegosiasikan

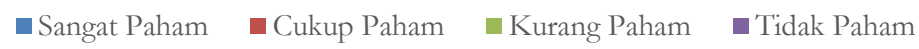

Grafik 2. Keuntungan bank syariah 
diambil oleh bank syariah dapat dinegosiasikan. Hal ini karena keuntungan telah ditetapkan oleh bank berdasarkan bagi hasil yang telah ditentukan, dan nasabah tidak berhak untuk menegosiasikannya. Beberapa konsumen lebih memilih bank syariah karena pembayaran bulanan mereka cenderung meningkat hingga akhir periode angsuran. Pelanggan lebih santai dalam perencanaan keuangan mereka ketika mereka memiliki jangka waktu tertentu. Pelanggan dihadapkan pada periode variabel, yang disebut tidak pasti, bila dibandingkan dengan kredit di bank tradisional, yang biasanya mengikuti suku bunga.

\section{Harga Perolehan Bank Syariah}

Penulis ingin mengetahui sejauh mana nasabah memahami kewajiban bank syariah dalam menyebutkan nominal harga perolehan yang akan diterima nasabah dan apakah nasabah mengetahui berapa biaya rumah dalam pemeriksaannya terhadap harga beli rumah di bank Syariah.
Grafik 3. menunjukkan banyak dari nasabah yang paham terhadap kewajiban bank syariah untuk menyebutkan seberapa besar harga perolehan dari rumah tersebut. Hal ini dikarenakan harga perolehan rumah tersebut pasti dicantumkan oleh bank syariah dalam kontrak yang ditandatangani oleh nasabah.

Untuk pemahaman tentang seberapa besar harga perolehan rumah yang ingin mereka ambil, nasabah mengetahui betul berapa besarnya harga perolehan rumah yang mereka ambil karena hal pertama yang menjadi pertimbangan nasabah dalam membeli rumah adalah harganya. Jadi nasabah pertama kali berhubungan dengan pengembang maupun penjual perorangan, ketika sudah terjadi persetujuan harga baru nasabah mengajukan ke bank syariah.

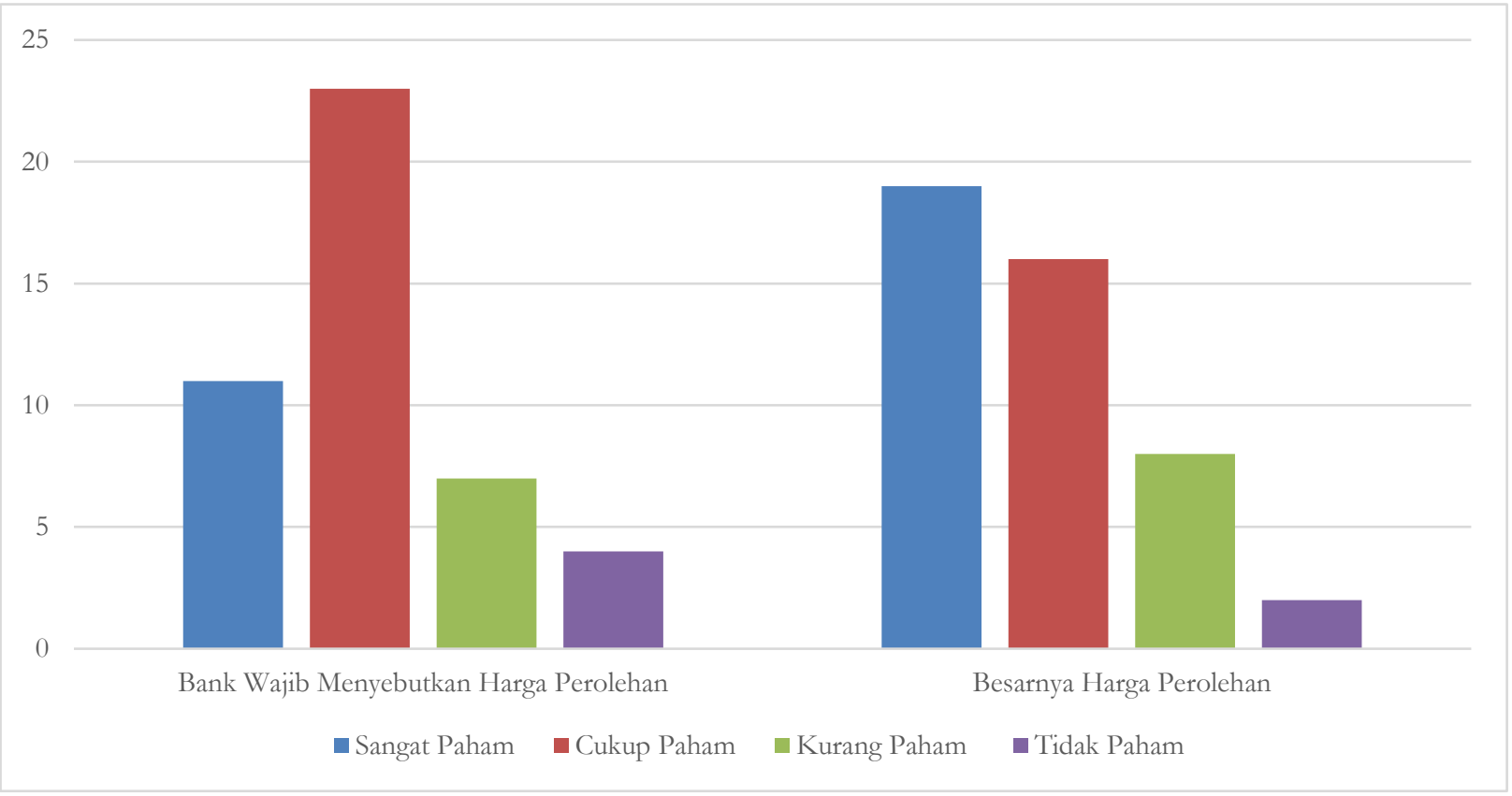

Grafik 3. Harga Perolehan 


\section{Diskon Pada Bank Syariah}

Penulis bertujuan untuk mengetahui seberapa besar tingkat pemahaman konsumen terhadap hak diskon yang diberikan pengembang kepada bank syariah sebelum dan sesudah akad dalam pemeriksaan diskon pada bank Syariah. pengembang saja yang mengetahui adanya pengurangan tersebut. Nurhayati dan Wasilah (2016) menyatakan bahwa harga beli menggunakan harga pokok yaitu harga beli dikurangi dengan diskon pembelian. Apabila diskon diberikan setelah akad, maka diskon

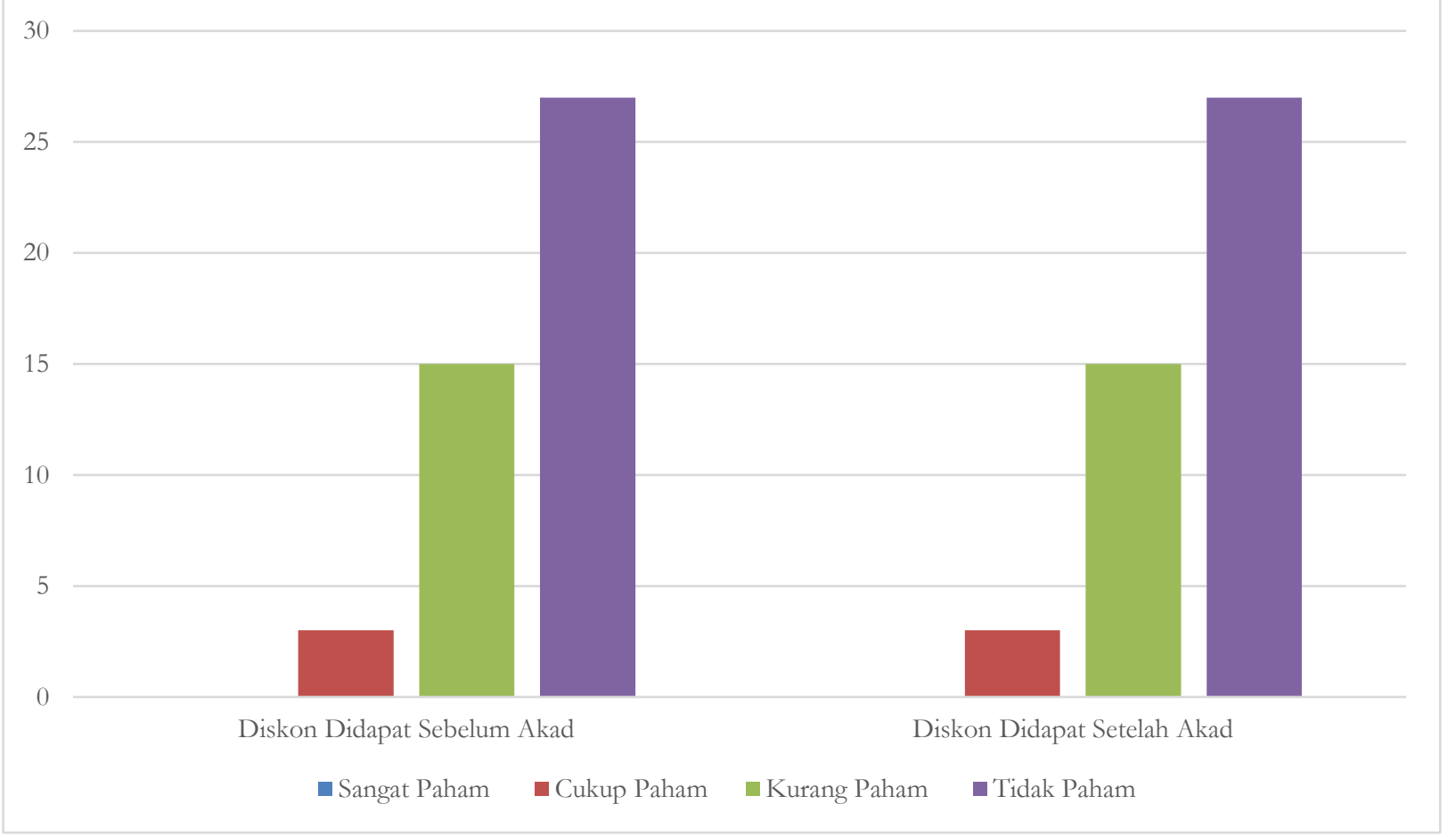

Grafik 4. Diskon Pada Bank Syariah

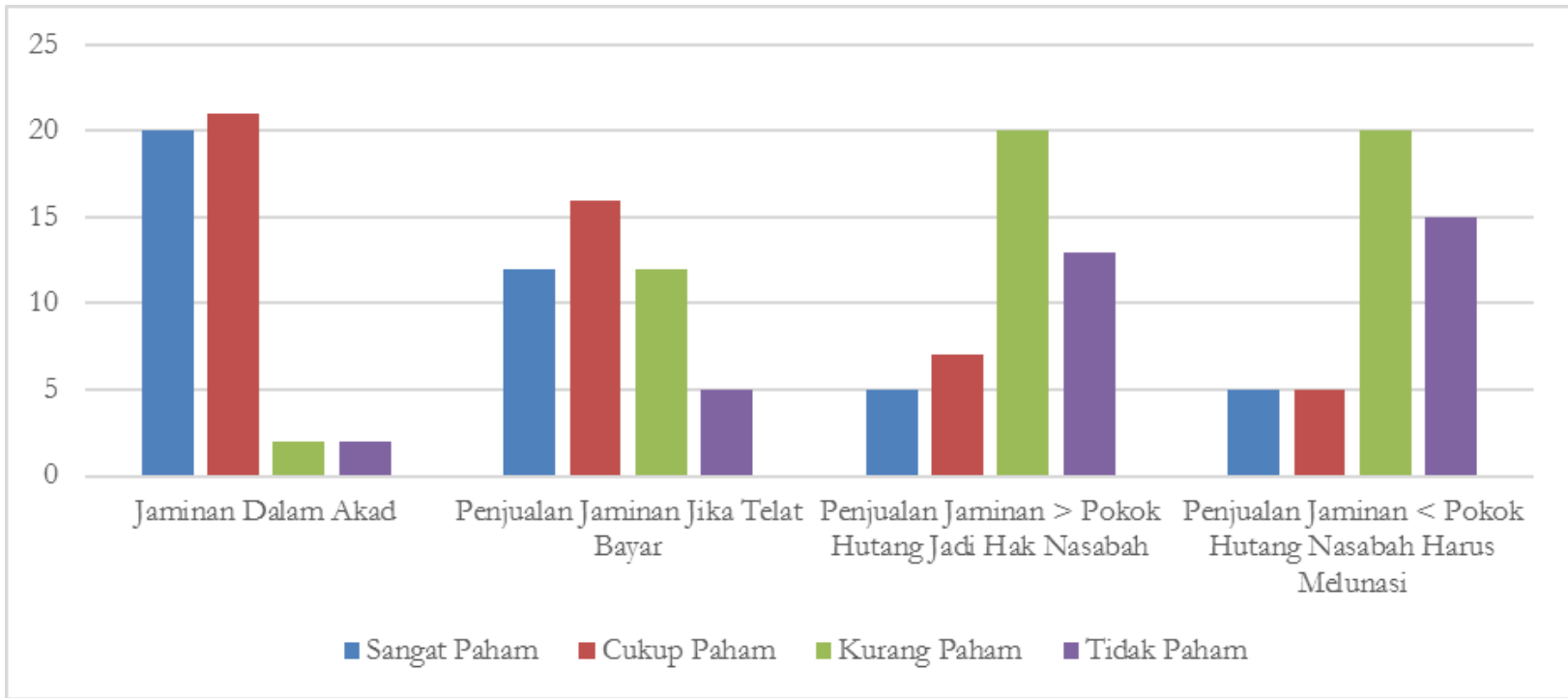

Grafik 5. Jaminan Pada Bank Syariah

Grafik 4. menunjukkan bahwa hampir semua nasabah tidak menyadari bahwa jika bank syariah menerima diskon dari pengembang sebelum atau setelah akad ditandatangani, nasabah berhak atas diskon. Sebab, pada kenyataannya konsumen tidak mengetahui adanya diskon tersebut, dan bank syariah serta yang didapat akan menjadi hak pembeli atau hak penjual sesuai dengan kesepakatan mereka diawal akad.

\section{Jaminan Pada Bank Syariah}

Penulis penelitian penjaminan pada bank syariah ini ingin melihat seberapa besar 
pemahaman nasabah terhadap peraturan yang menyatakan bahwa bank syariah berhak meminta jaminan kepada nasabah, kemudian apakah nasabah memahami apakah jaminan tersebut dapat dijual oleh bank syariah jika pelanggan terlambat membayar atau tidak membayar. bersedia bekerja sama dengan lembaga keuangan Islam. Penulis juga ingin mengetahui apakah nasabah menyadari bahwa jika rumah dijual melebihi utang pokok, selisihnya menjadi hak nasabah. Jika harga jual yang dijamin lebih kecil dari utang pokok, selisihnya menjadi tanggungan nasabah.

Grafik 5. menunjukkan dalam setiap transaksi kredit, baik itu akad murabahah di bank syariah atau kredit di bank konvensional, sebagian besar konsumen memahami jaminan yang berhak diminta oleh bank syariah. Karena tidak ada yang bisa mengikat konsumen dan bank jika transaksi kredit tidak dijamin.

Sebagian besar nasabah memahami penjualan agunan jika nasabah terlambat membayar dan menolak bekerja sama dengan bank syariah. Karena aturan ini dijabarkan secara rinci dalam kontrak yang ditandatangani pelanggan.

\section{Denda Pada Bank Syariah}

Studi penulis tentang denda pada bank syariah ini ingin mengetahui seberapa baik nasabah memahami pedoman yang menyatakan bahwa jika nasabah dengan sengaja menunda pembayaran, hukumnya haram. Penulis kemudian ingin memeriksa apakah klien menyadari bahwa jika mereka melewatkan pembayaran angsuran karena bukan kesalahan mereka sendiri, bank akan memberi mereka istirahat. Penulis juga ingin mengetahui apakah klien menyadari berapa denda yang harus mereka bayar jika tidak mampu membayar cicilan. Pelanggan juga harus memahami bahwa denda yang mereka bayar diakui sebagai uang yang bermanfaat, bukan bank pendapatan syariah, menurut penulis. Terakhir, penulis ingin mengetahui apakah klien mengetahui bahwa bank syariah memiliki wewenang untuk membebankan semua biaya penagihan bank kepada mereka.

Dari grafik 6. dapat dilihat bahwa beberapa klien tidak menyadari bahwa dengan sengaja menunda pembayaran adalah ilegal, meskipun mereka memiliki kemampuan untuk melakukannya. Hal ini disebabkan kurangnya sosialisasi bank syariah saat melakukan akad. Selain itu, klien tidak memiliki keinginan yang kuat untuk belajar tentang aturan biasa kontrak murabahah.

Banyak klien tidak menyadari undang-undang yang mengharuskan bank syariah untuk memberikan konsesi kepada pelanggan yang

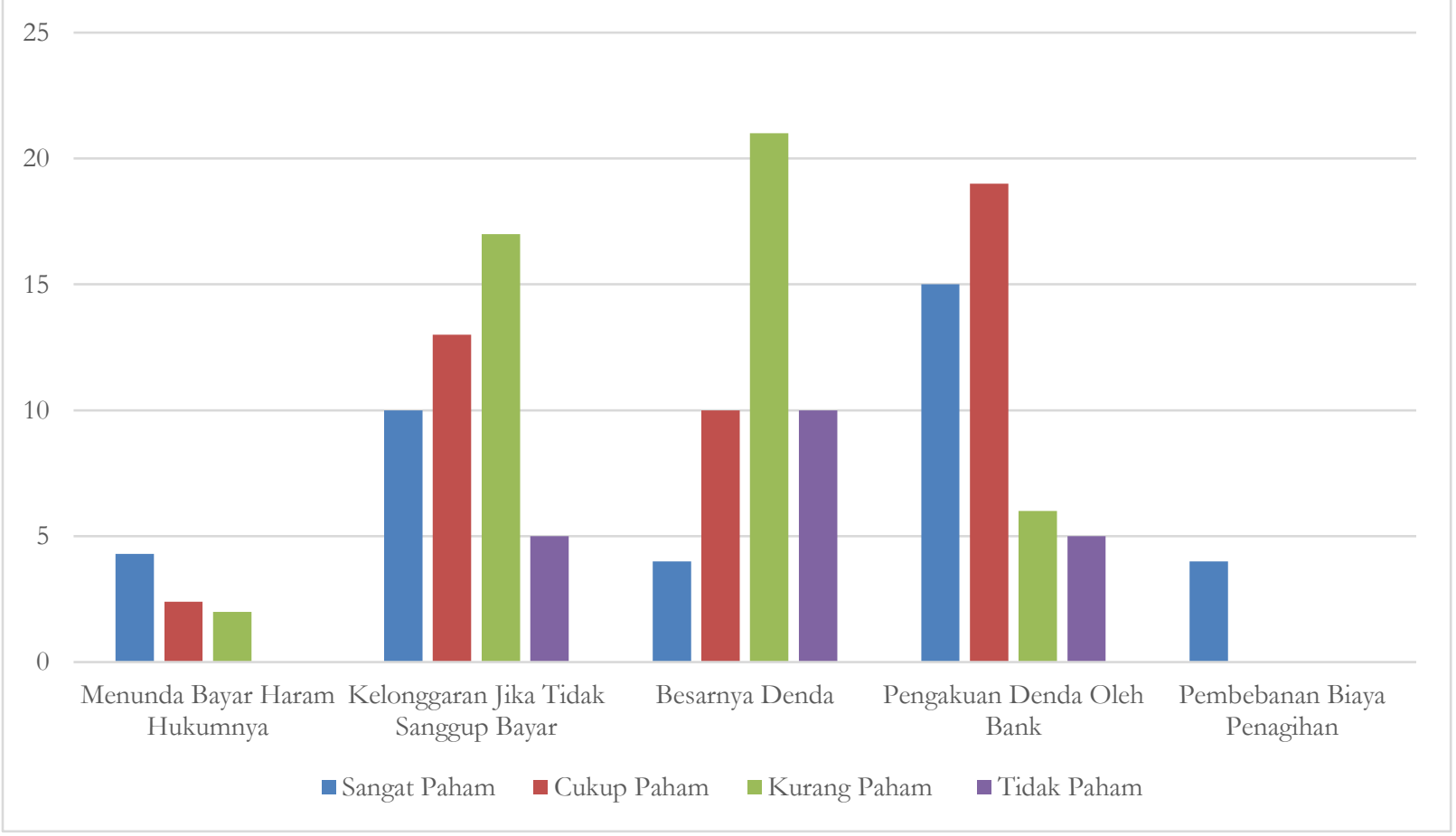

Grafik 6. Denda Pada Bank Syariah 
tidak mampu membayar karena keadaan di luar kendali mereka. Hal ini disebabkan fakta bahwa bank tidak mematuhi aturan. Bank syariah tidak terkecuali bagi konsumen yang tidak mampu membayar cicilannya. Bank syariah tidak jauh berbeda dari bank normal dalam hal ini.

\section{Pelunasan Pada Bank Syariah}

Penelitian penulis tentang denda bank syariah tertarik untuk menentukan seberapa besar pemahaman nasabah atas haknya memungkinkan mereka untuk mengembalikan kontrak pembiayaan murabahah lebih awal. Selain itu, jika nasabah ingin melakukan pelunasan lebih awal, penulis ingin mengetahui apakah konsumen memahami perhitungan bonus atau denda dalam akad murabahah. hutang yang belum dibayar. Beberapa pelanggan, di sisi lain, bingung karena mereka tidak mempertimbangkan untuk membayar di muka dan dengan demikian tidak mengetahui perhitungannya.

Menurut Tarmizi (2012), harga, serta jumlah syarat dan jangka waktu, harus satu dan jelas dalam transaksi jual beli kredit agar sah. Akibatnya tidak halal bagi penjual (bank syariah) untuk mengambangkan harga dengan menawarkan diskon harga yang ekstrim dengan pembayaran penuh, yaitu jika pembeli membayar sebelum tanggal jatuh tempo, harga akan turun secara proporsional.

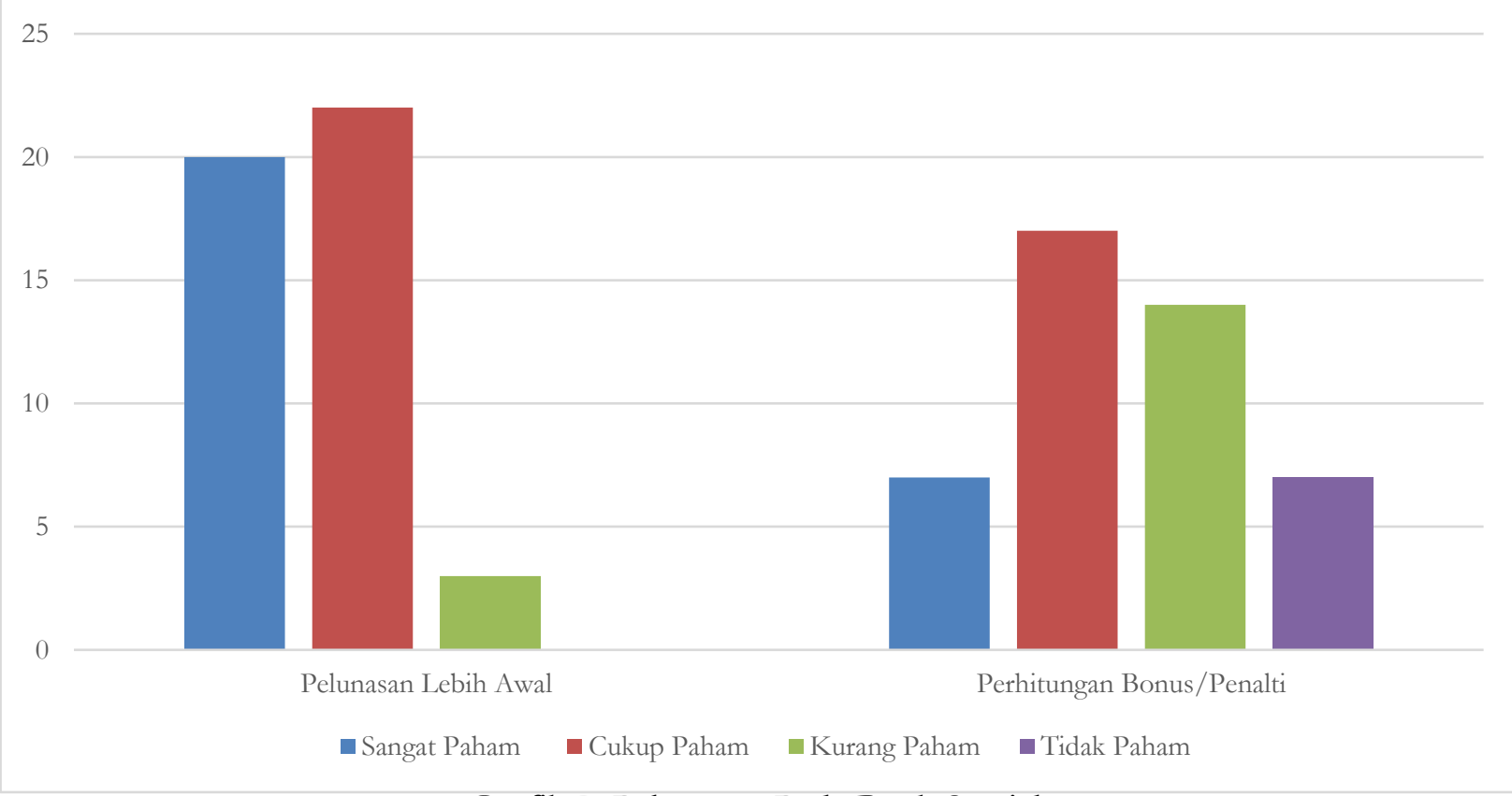

Grafik 7. Pelunasan Pada Bank Syariah

Pada grafik 7. Diketahui hampir banyak nasabah menyadari hak mereka untuk melakukan pelunasan lebih awal, karena ketika mereka menandatangani kontrak dengan bank, mereka dapat memulai dan menjelaskan dalam kontrak bahwa mereka dapat melakukan pelunasan lebih awal. Sebagian nasabah sudah familiar dengan perhitungan bonus atau denda dalam melakukan pelunasan lebih awal karena juga menjadi salah satu pertimbangan nasabah saat memilih bank syariah. Beberapa klaim cerdas untuk menerima diskon satu kali untuk melihat lebih awal, sementara yang lain mengklaim menerima diskon tergantung pada

\section{Kesimpulan}

Tujuan dari penelitian ini adalah untuk melihat persepsi nasabah terhadap pembiayaan murababah dan variabel-variabel yang mendorong mereka untuk menggunakannya. Berdasarkan studi bab sebelumnya, kesimpulan berikut dapat ditarik:

1) Sebagian besar nasabah tidak mengenal akad murabahah. Hal ini disebabkan karena bank syariah tidak mensosialisasikan informasi mengenai pembiayaan akad murabahah, sehingga nasabah kurang memiliki keahlian yang sesuai. Selain itu, 
ditemukan bahwa banyak bank syariah gagal menjelaskan syarat-syarat kontrak secara memadai kepada konsumen, meskipun sistem pengenalan yang kompeten adalah salah satu persyaratannya.

2) Perbedaan perhitungan angsuran atau angsuran dengan bank konvensional, dimana bank syariah memiliki sistem angsuran tetap atau tidak mengikuti suku bunga untuk memudahkan perencanaan keuangan nasabah, menjadi salah satu faktor nasabah memilih akad murabahah sebagai sumber pembiayaan yang ditemukan dalam penelitian ini. Selanjutnya, jika dibandingkan dengan bunga kredit yang dikenakan oleh bank biasa, bank syariah mengenakan margin keuntungan yang lebih rendah. Beberapa konsumen menggunakan bank syariah sebagai sumber pendanaan karena mereka ingin menghindari pembayaran bunga dan tidak memiliki pilihan lain.

\section{Daftar Pustaka}

Antonio, M. S. I. (2001). Bank Syariah: dari teori ke praktik. Gema Insani.

DSAK, I. (2009). Pernyataan Standar Akuntansi Keuangan. Jakarta, Ikatan Akuntan Indonesia (LAI) dan Penerbit Salemba.

Karim, Adiwarman A (2001). Ekonomi Islam: Suatu Kajian Kontemporer. Jakarta: Gema Insani Press.

Nurhayati, Sri \& Wasilah (2016). Akuntansi Syariah di Indonesia. Jakarta: Salemba Empat.

Perwataatmadja, Karanaen A. \& Muhammad Syafi'i Antonio (1999). Apa dan Bagaimana Bank Islam. Yogyakarta: P.T. Dana Bhakti Prima Yasa.
Rachmawati, W., Karim, A., \& Manan, A. (2019). Optimalisasi Pembiayaan Murabahah Berprinsip Bagi Hasil Pada Bank Syariah Di Indonesia 20102015. Jurnal Dinamika Sosial Budaya, 20(2), 158-170.

Saeed, Abdullah (2004). Menyoal Bank Syariah: Kritik atas Interpretasi Bunga Bank Kaum Neo-Revivalis, terj. Arif Maftuhin. Jakarta: PARAMADINA.

Sudarsono, Heri (2004). Bank dan Lembaga Keuangan Syariah: Deskripsi dan Ilustrasi. Yogyakarta: EKONISIA.

Tarmizi, Erwandi (2012). Harta Haram Muamalat Kontemporer. Bogor: P.T. Berkat Mulia Insani Publishing

Undang-Undang, R. I. (1998). Nomor 10 tahun 1998 Tentang Perubahan Atas UndangUndang Nomor 7 tahun 1992 Tentang Perbankan. Lembaran Negara Republik Indonesia.

Undang-Undang, R. I. (1998). Nomor 10 tahun 1998 Tentang Perubahan Atas UndangUndang Nomor 7 tahun 1992 Tentang Perbankan. Lembaran Negara Republik Indonesia.

Widodo, S. (2010). Seluk beluk jual beli murabahah perspektif aplikatif. Yogyakarta: Asgard Chapter.

Zaid, Z., \& Rehman, A. U. (2020). Bank Resilience Over The Business Cycle In A Dual Banking System. International Journal of Business and Economics, 5(2), 24-41. 